\title{
Superabsorbent polymers to seal and heal cracks in cementitious
}

\section{materials}

\author{
Didier Snoeck ${ }^{\mathrm{a}^{*}}$ \\ a Magnel Laboratory for Concrete Research, Department of Structural Engineering, Faculty of Engineering and Architecture, Ghent University, \\ Tech Lane Ghent Science Park, Campus A, Technologiepark Zwijnaarde 904, B-9052 Gent, Belgium
}

Received: 02 July 2018 / Accepted: 02 November 2018 / Published online: 15 November 2018

(C) The Author(s) 2018. This article is published with open access and licensed under a Creative Commons Attribution 4.0 International License.

\begin{abstract}
Superabsorbent polymers (SAPs) are promising admixtures to improve properties in cementitious materials. Not only useful to mitigate autogenous shrinkage and to increase the freeze-thaw resistance, SAP particles may enhance self-sealing and self-healing in cementitious materials. The self-sealing leads to a regain in water tightness and promoted autogenous healing may prove to be useful to limit repair works caused by concrete cracking. By providing sufficient building blocks for healing, limiting the crack width by means of synthetic microfibers and inducing water by means of SAPs, a smart cementitious material is obtained. This material can be an excellent material to use in future building applications such as tunnel works and groundretaining structures. This paper gives an overview of the current status of the research on SAPs in cementitious materials to obtain sealing and healing.

Keywords: Self-sealing; Self-healing; Multiple cracking; Strain-hardening cementitious composite; Hydrogels; Superabsorbent polymers
\end{abstract}

\section{Introduction}

Concrete is prone to cracking and the cracks interconnect flow paths for water, possibly containing harmful substances. The ingress of water could induce steel corrosion, frost attack, chemical attack and internal expansion, endangering the durability of a structure. A cementitious material which has the property to stop or to partially prevent water movement in a crack would therefore have a clear added value. Additionally, complete closure of cracks and a regain in mechanical properties are wanted. Promising admixtures to promote these features are superabsorbent polymers.

Superabsorbent polymers (SAPs) are natural or synthetic water-insoluble three-dimensional networks of polymeric chains cross-linked by chemical or physical bonding. They are able to take up a significant amount (up to 500 times their own weight) in fluids from the environment. The swelling is closely related to the osmotic pressure when put in a liquid and can be investigated using different techniques [1, 2]. If this fluid is water, they are also often called hydrogels. Hydrogels are used nowadays in contact lenses, scaffolds in tissue engineering, smart sustained-release delivery systems, human health care products and other applications [3]. Furthermore, this polymer quickly found its application in cementitious composites [4-6]. SAPs can be used in cementitious materials for reducing the autogenous shrinkage (internal curing) [7-12], for changing the rheology of the fresh material [13], and for increasing the freeze/thaw resistance [14], amongst others. In prior research, the mitigation of autogenous shrinkage was investigated on samples with and without additional supplementary cementitious materials such as fly ash and blast-furnace slag [10]. Furthermore, the effectiveness of SAPs for internal curing was investigated using Nuclear Magnetic Resonance $[11,12,15]$. The kinetics release of water from the SAPs towards the cementitious matrix during cement hydration could clearly be monitored [11]. These kinetics were also studied by means of neutron radiography [16] and used for modelling internal curing by SAPs [17]. This sheds new light on the internal curing mechanism. After they have released their water for internal curing, they will be able to re-swell to full extent once in contact with a liquid. In this paper, the use of superabsorbent polymers to seal and heal cracks is discussed.

\section{Self-sealing}

As superabsorbent polymers are able to swell, they will also absorb part of the mixing water. Doing so, they will affect the workability and cause the formation of macro pores, a

* Corresponding author: Didier Snoeck, E-mail: didier.snoeck@UGent.be 
change in effective water-to-cement ratio, a densification due to internal curing and a change in microstructure if no additional water is added [18]. To counteract this, additional water is added on top to compensate for the loss in workability, leading to more or less the same microstructural properties $[18,19]$. However, macro pores remain present, possibly reducing the mechanical properties $[19,20]$. To limit the influence of the swelling SAPs on the mechanical properties, pH-sensitive SAPs [21, 22] or coated SAPs [23] may be used. This research is ongoing and new SAPs will be synthesized and produced in order to limit the influence on the mechanical properties in systems with high water-tocement ratios.

Due to their swelling capacity upon contact with fluids, SAPs may cause a decrease in permeability of cracked cementitious materials. When liquids enter a crack, SAP particles along the crack faces will swell and block the crack [24-27]. Application of a superabsorbent resin in situ to repair concrete leakage can also be used, but this is rather considered to be manual repair [28]. To determine the water movement through a specimen, several methods can be used, both destructive and non-destructive [29]. A possibility is the use of a water permeability test set-up. However, in this method, the crack sealing potential of SAP particles cannot be visualized, only measured. In this test, specimens containing SAPs initially show a decrease in permeability. This is mainly due to the swelling effect of SAPs and blockage of the crack by SAPs. The decrease in water permeability is thus a measure for the sealing capacity. A further decrease in water permeability is due to the blockage by loose particles and SAPs. In 100-300 $\mu \mathrm{m}$ wide cracks, SAPs with a size of approximately $500 \mu \mathrm{m}$ are better in terms of sealing compared to $100-\mu \mathrm{m}$ sized SAPs as the latter are washed out and are not able to fill cracks, even though high amounts (1 $\mathrm{m} \%$ of cement weight) are used $[27,30,31]$. It was also found that due to the swelling effect of the SAPs, the reduced water movement speed, which is critical to obtain autogenous healing, is optimal as cracks are able to close due to deposited crystals. In reference specimens, the amount of autogenous healing - inherent part of a cementitious system - is less compared to the specimens with SAPs. As the water speed may be high in reference samples, possible healing products are likely to be washed out. In water-retaining structures like quays or cellars the SAPs may prove to be useful as the flow will be reduced, sealing the cracks, but the crack may by sealed by deposited crystals as well.

In another practical test on large-scale beams using a simple mounted water basin [32], a decrease in water ingress was found through cracks with SAPs. Furthermore, using cryofracture scanning electron microscopy, the swelling inside specimens could be investigated [33]. It was found that SAPs swell across voids including cracks, causing a sealing of the cementitious material [33]. Currently, new models are proposed to model self-sealing by means of SAPs $[34,35]$ in order to increase their application in the field.

By means of neutron radiography, the self-sealing effect could be studied in detail [27] (Fig. 1). On small cylindrical samples ( $\varnothing 10 \mathrm{~mm} \times 20 \mathrm{~mm}$ ), a water head of $20 \mathrm{~mm}$ was placed. The water permeability of the cracked samples without SAPs and the cracked samples containing $1 \mathrm{~m} \%$ SAPs was studied in time. The water head in specimens without SAPs lowers rapidly in time. However, the water head in specimens with SAP particles decreases only slightly in time due to the blockage of the crack due to the swelling action by the SAPs.

Self-sealing is related to the initial decrease in permeability and is not permanent. This is important to know as a possible temporal self-sealing effect may not lead to a regain in mechanical properties. This regain on the other hand is the result of self-healing.

\section{Reference sample:}
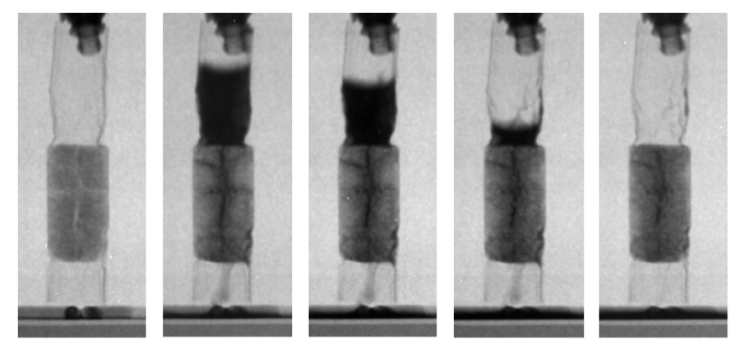

SAP sample:

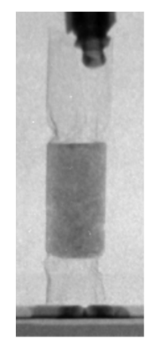

$0 \mathrm{~s}$

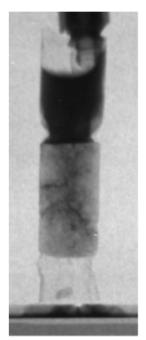

$1 \mathrm{~s}$

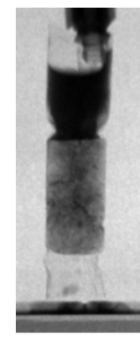

$10 \mathrm{~s}$

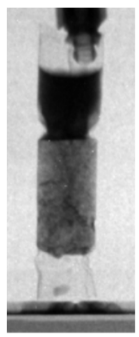

$30 \mathrm{~s}$

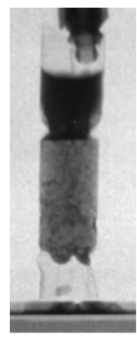

$60 s$
Figure 1. Cracked specimens containing $1 \mathrm{~m} \%$ SAP particles are able to withstand a water head due to their swelling effect.

\section{Self-healing}

Concrete has a passive healing capacity of its own, also called autogenous healing as unhydrated cement particles always remain present in a hardened cementitious matrix. As water flows into the cracks, continued hydration of these unhydrated cement grains produces new calcium silicate hydrates (C-S-H), which can result in sealing of small cracks. Another main mechanism of autogenous crack healing is the precipitation of calcium carbonate $\left(\mathrm{CaCO}_{3}\right)$ which also blocks the crack [36, 37]. Two inferior mechanisms are the blockage by impurities and broken off particles in the fluid or of the cementitious matrix, and the swelling of $\mathrm{C}-\mathrm{S}-\mathrm{H}$.

There are three needed conditions for autogenous crack healing to occur. These are the presence of specific chemical substances $\left(\mathrm{Ca}^{2+}, \mathrm{CO}_{2}\right.$, etc.); the exposure to humid environmental conditions (wet/dry cycles, submersion in water, etc.) and restricted crack widths up to $30-50 \mu \mathrm{m}$ for 
strain-hardening mixtures $[30,38]$. Self-healing prevails in a variety of environmental conditions even when the composite is deliberately damaged by tensioning to several percentages strain. But the healing is limited and needs to be stimulated. At $95 \%$ relative humidity $(\mathrm{RH})$, there was no healing visible and it was concluded that the presence of water as curing medium was essential. A dedicated material design can promote the autogenous healing capacity. Two possible mechanisms and their combined effect are highlighted in this study.

The first mechanism is the introduction of microfibers to obtain fibre-reinforced cementitious materials with a high tensile ductility, as studied in [38, 39]. These composites exhibit tensile strain-hardening behaviour achieved by matrix multiple cracking (left part of Fig. 2). The best overall self-healing mixture had a fly-ash-to-cement ratio of 1 , a fine-sand-to-binder ratio of 0.35 , a water-to-binder ratio of 0.30 , a superplasticizer-to-binder ratio of 0.0097 and $2 \mathrm{v} \%$ of oil-treated polyvinyl alcohol (PVA) microfibers [31].

The second healing mechanism is the use of SAPs, improving/promoting the obtained autogenous healing capacity (right part in Fig. 2). The use of SAPs to promote autogenous healing is dual. The macro pores formed act as initial flaws and promote multiple cracking $[40,41]$, leading to an enhanced ductility. Secondly, SAP-particles are useful for autogenous healing as they absorb water during wet periods and slowly release it during dry periods. SAPs can contribute to the internal healing of a crack after performing wet/dry cycles [30, 42]. Internal-water supply by means of SAPs has a positive influence on the amount of stimulated autogenous healing. SAPs can sustain hydration by yielding their absorbed water and provide water for the formation of healing products.
Cracks smaller than $30 \mu \mathrm{m}$ exposed to wet/dry cycles healed completely both with and without SAPs. Cracks between 50 $\mu \mathrm{m}$ and $150 \mu \mathrm{m}$ healed partly in samples without SAP, but sometimes even a $138 \mu \mathrm{m}$ crack closed completely after 28 wet/dry cycles in a specimen containing SAPs [30]. Cracks larger than $200 \mu \mathrm{m}$ showed almost no healing.

SAPs have a dual effect on the strength. On one hand they will increase the strength due to the further hydration by the release of mixing water in time during hardening of the cementitious matrix (i.e. due to internal curing). But, on the other hand, they will decrease the strength due to the formation of macro pores. Both influences combined leads in this case to an equivalent first-cracking-strength in these strain-hardening mixtures with a low water-to-binder ratio. The amounts of SAPs were limited to $1 \mathrm{~m} \%$. This amount of SAPs is rather high compared to literature, as only 0.2-0.6 $\mathrm{m} \% \mathrm{SAP}$ is used to reduce the autogenous shrinkage [4].

To a certain degree the autogenous healing capability of cementitious materials is maintained during subsequent loading cycles. SAP particles promote the self-healing ability by renewed internal curing upon crack formation and this leads to regain of mechanical properties such as the firstcracking-strength. In wet/dry cycles, the plain material without superabsorbent polymers is able to regain $45 \%$ of its first-cracking-strength after a first healing cycle. After the second healing cycle, this regain is $28 \%$. When superabsorbent polymers are used, the regain is $75 \%$ and $66 \%$, respectively [43]. Possible explanations are the storage of a calcium-rich fluid (i.e. the pore solution) in the swollen SAPs, and the reduced permeation through the crack. This provides the possibility of the formation of the $\mathrm{CaCO}_{3}$ crystals in the crack. This causes the ideal conditions for promoted autogenous healing.

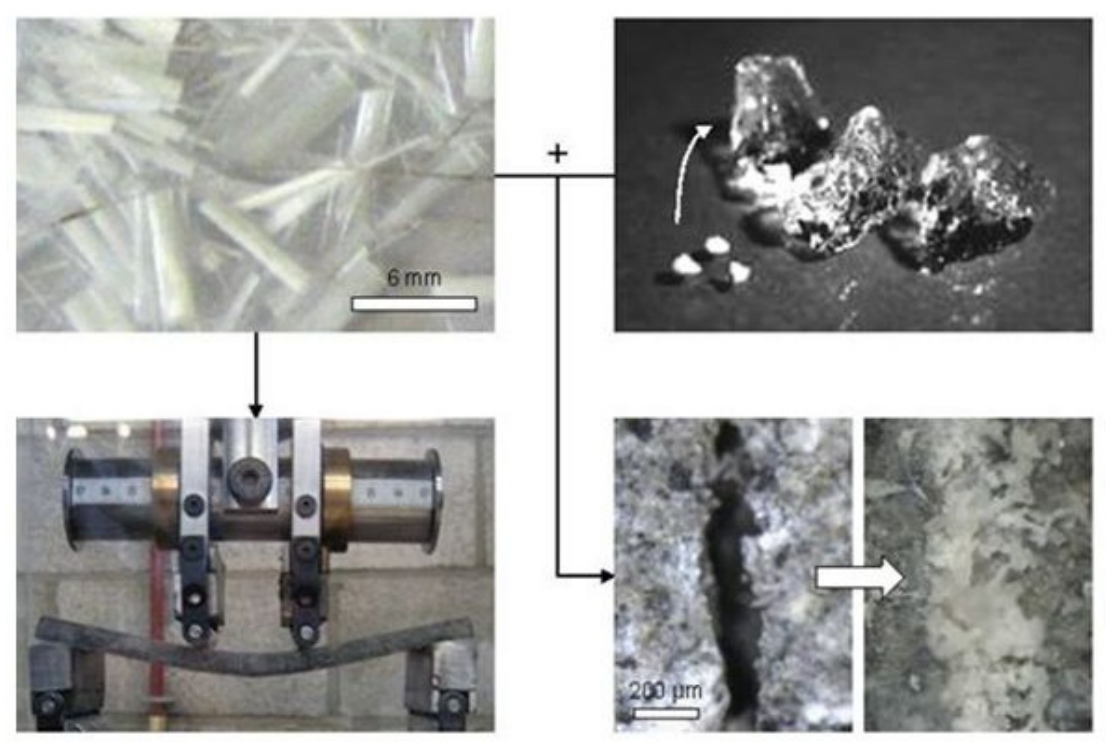

Figure 2. General overview of the combination of microfibers and SAPs to receive multiple cracking with small healable cracks and the stimulation of autogenous healing. 
When not completely submerged in water, only samples containing SAPs showed self-healing properties due to moisture uptake $[30,44]$. Even in an environment with a $\mathrm{RH}$ $>90 \%$, there is a non-negligible healing noticeable, due to their moisture uptake capacity. If reference samples are stored in a climate room with a certain relative humidity, there is almost no autogenous healing as water is not present to form the healing products. The samples with SAPs do show a regain in strength when stored in a relative humidity of more than $90 \%$. The moisture uptake by SAPs (up to four times their own weight in moisture [18]) seems to be sufficient to promote a certain degree of autogenous healing, especially in the interior of the crack in the form of further hydration. In the relative humidity condition of more than $90 \%$, the material with $1 \mathrm{~m} \%$ shows a regain of $60 \%$. At the crack mouth, the crack was still clearly open and only at some distinct places, there was some bridging of a crack by healing products.

The formation of healing products could be visualized by means of X-ray $\mu \mathrm{CT}$ scanning, using cracked cylindrical specimens with a height of $10 \mathrm{~mm}$ and a diameter of $6 \mathrm{~mm}$ [45]. The crack width was approximately $100 \mu \mathrm{m}$ in all samples. The original unhealed state was subtracted from the healed scans. The results are shown in Fig. 3.

In reference samples (Fig. 3a-c), most healing (yellow) is found after being stored in wet/dry cycles for 28 days. The healing products are formed at the top and bottom of the specimen near the surface of the crack from 0 till 800-1000 $\mu \mathrm{m}$ inside the crack [45]. The largest amount is found in the region 0-100 $\mu \mathrm{m}$ below the surface. In the interior of a crack, the amount of healing products is less and only at some distinct places, the healing products bridge a crack, probably in the vicinity of a fibre (as they act as a nucleation site for the calcium carbonate crystals).

No healing is seen in reference samples stored at $\mathrm{RH}$ conditions (Fig. 3a-b). The drawback, even though it is a high-resolution X-ray, is the resolution itself. As the voxel size of a $6 \mathrm{~mm}$ sample was $6 \mu \mathrm{m}$, artefacts and areas smaller than $12 \mu \mathrm{m}$ could not be seen. If a lower voxel size is needed, the sample needs to be smaller, but this would lead to non-representative results. These small healing products, if present, could not be visualized.

The cementitious materials are best healed in wet/dry cycles and when SAP particles are mixed in, mainly due to the availability of water during dry periods. Some healing product formation can be found near SAP particles stored in a RH condition (Fig. 3d-e). This can be the formation of healing products due to the release of moisture from the SAP to the local cementitious matrix. Abundant crystal formation is seen in samples with SAPs stored in wet/dry cycles (Fig. 3f).

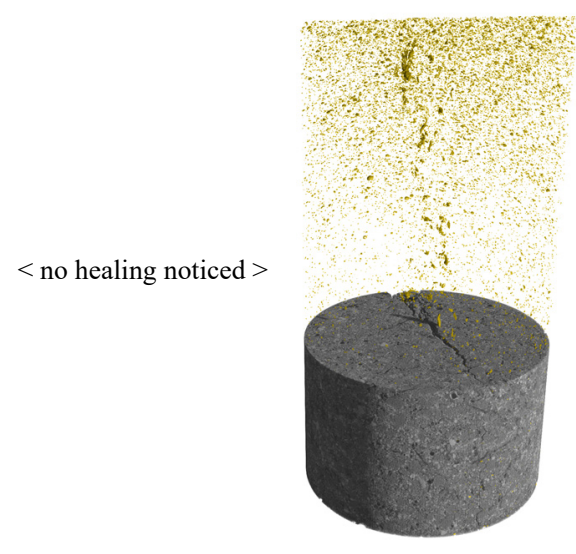

(a)

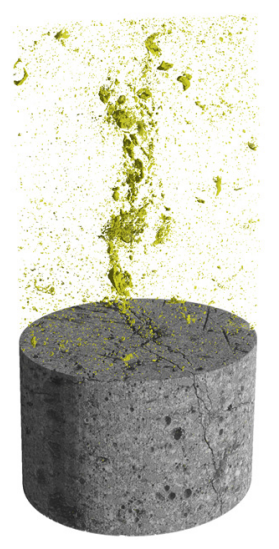

(d) (b)

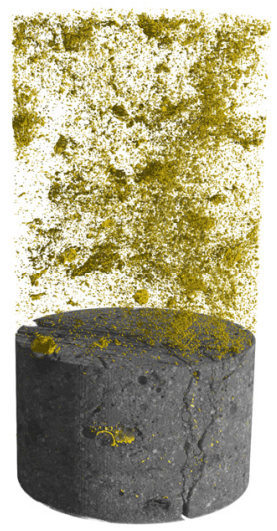

(e)

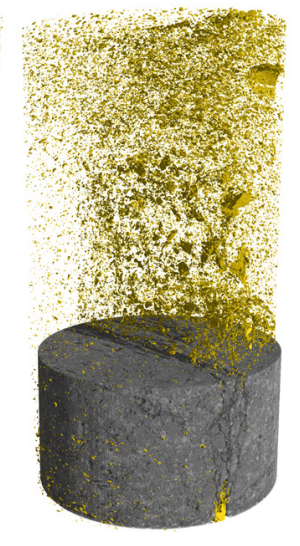

(c)

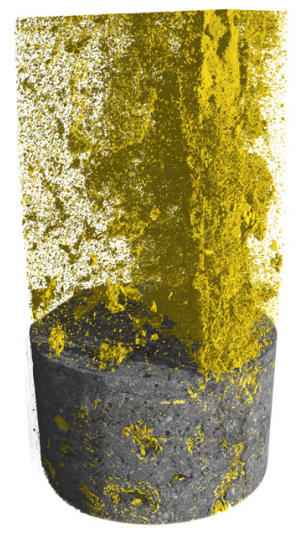

(f)

Figure 3. Amount of healing products (yellow) in 28 days old specimens without (a-c) and with SAPs (d-f) stored at a relative humidity of $60 \pm$ $5 \%(a, d), 95 \pm 5 \%(b, e)$ and in wet/dry cycles (c, f). 
Bacteria can be added to a hydrogel, further improving the overall amount of healing products $[46,47]$, if wider cracks are to be expected.

\section{Conclusions and future aspects}

Possible applications of the self-sealing and self-healing material are widely spread. Water-retaining structures may benefit and construction companies may be interested. The principle of using SAPs has its possible applications for the industry. Contractors are searching for a way to decrease shrinkage cracks and to obtain a watertight structure. This is especially important for tunnel elements, underground parking garages, basements, liquid containing structures, pavements, etc. Nowadays, contractors are often forced to apply crack repair right after construction, due to the formation of shrinkage cracks and thermal cracks at early age. The shrinkage could be overcome by using SAPs as they may provide internal curing to the construction element: they absorb water in the fresh concrete mix, and provide it to the cement particles at the right moment in the hydration process, in this way reducing the autogenous shrinkage. In hardened concrete, they may seal occurring cracks, as they swell in contact with intruding water. This may reduce the uptake of harmful substances, most likely leading to an enhanced long-term durability and service life. The SAPs will subsequently promote autogenous healing of the crack since they provide water for further hydration of yet unhydrated cement particles and calcium carbonate precipitation, leading to even more tight structures and possible regain of the mechanical properties.

Micro-fibre reinforced strain-hardening cementitious composites possess the qualities of a high-strength concrete combined with tensile ductility and crack width control. Their small cracks are interesting in terms of autogenous healing where only small cracks are able to heal completely, further stimulated by SAPs. Combined with (promoted) selfhealing it is a durable material and very promising to use in the future. In regions with wet/dry cycles, water remains present in the SAPs during the dry periods. Therefore, selfhealing can prevail at all times. However, performancebased durability concepts are still required to get a durability design framework for these strain-hardening materials [48].

Furthermore, due to the self-compacting properties of the strain-hardening mixture, thin forms are achievable [49]. Nature fits form to function, rewards cooperation and curbs excess form within. This is also true for this material; the accretion of material to places where it is most needed, resulting in adaptive structures. The form should be ideal to transfer loads, so that an excess of material can be removed. This material will result in lighter and safer structures, leading to a reduced safety factor as the structure may reach its optimal design.

The role of autogenous healing on corrosion prevention will also be important in the future. If cracks are not sealed, water containing aggressive substances will break down the passive film on the reinforcements. This aspect needs to be considered when autogenous healing is used in real-life structures. The maintenance and longevity of these structures is hereby very important.

One general conclusion can be made; one should continue to build with nature's rules. The bleeding (water for SAPs), blood cells (building blocks), blood flow vascular network (porous concrete), blood clothing (formation of healing products near synthetic microfibers), skeleton and bone healing (crystallization) are only a few properties studied in the field of construction healing. By mimicking nature to enhance performance, more durable constructions will be designed, leading to a higher service life and better overall life quality.

\section{Acknowledgements}

The support and advice of my promotor Nele De Belie is greatly appreciated. Ole Mejlhede Jensen and Leo Pel are greatly thanked for their warm welcome during several research stays. The great work of the RILEM TC-225 SAP and TC-260 RSC, hosted by Viktor Mechtcherine, is also acknowledged.

As a Postdoctoral Research Fellow of the Research Foundation-Flanders (FWO-Vlaanderen), D. Snoeck would like to thank the foundation for the financial support (12J3617N).

\section{References}

[1] V. Mechtcherine et al., Testing superabsorbent polymer (SAP) sorption properties prior to implementation in concrete: results of a RILEM Round-Robin Test. Mater Struct (2018) 51:28. https://doi.org/10.1617/s11527-018-1149-4

[2] C. Schröfl, D. Snoeck, V. Mechtcherine, A review of characterisation methods for superabsorbent polymer (SAP) samples to be used in cement-based construction materials - Report of the RILEM TC 260RSC. Mater Struct (2017) 50(197): 1-19. https://doi.org/10.1617/s11527-017-1060-4

[3] F.L. Buchholz, A.T. Graham, Modern superabsorbent polymer technology, Wiley-VCH, New-York, 1998.

[4] V. Mechtcherine, H.W. Reinhardt, Application of Super Absorbent Polymers (SAP) in Concrete Construction, State-of-the-Art Report Prepared by Technical Committee 225-SAP. Springer, 2012, p. 165. https://doi.org/10.1007/978-94-007-2733-5

[5] V. Mechtcherine, Use of superabsorbent polymers (SAP) as concrete additive. RILEM Tech Lett (2016) 1: 81-87. https://doi.org/10.21809/rilemtechlett.2016.18

[6] A. Mignon, D. Snoeck, P. Dubruel, S. Van Vlierberghe, N. De Belie, Crack Mitigation in Concrete: Superabsorbent Polymers as Key to Success? Mater (2017) 10(3 (237)): 1-25. https://doi.org/10.3390/ma10030237

[7] O.M. Jensen, P.F. Hansen, Water-entrained cement-based materials I. Principles and theoretical background. Cem Concr Res (2001) 31(4): 647-654. https://doi.org/10.1016/S0008-8846(01)00463-X

[8] O.M. Jensen, P.F. Hansen, Water-entrained cement-based materials II. Experimental observations. Cem Concr Res, (2002) 32(6): 973978. https://doi.org/10.1016/S0008-8846(02)00737-8

[9] V. Mechtcherine et al., Effect of Internal Curing by Using Superabsorbent Polymers (SAP) on Autogenous Shrinkage and Other Properties of a High-performance Fine-grained Concrete: Results of a RILEM Round-robin Test, TC 225-SAP. Mater Struct (2014) 47(3): 541-562. https://doi.org/10.1617/s11527-013-0078-5

[10] D. Snoeck, O.M. Jensen, N. De Belie, The influence of superabsorbent polymers on the autogenous shrinkage properties of cement pastes with supplementary cementitious materials. Cem Concr Res (2015) 74: 59-67. https://doi.org/10.1016/j.cemconres.2015.03.020 
[11] D. Snoeck, L. Pel, N. De Belie, The water kinetics of superabsorbent polymers during cement hydration and internal curing visualized and studied by NMR. Sci Rep (2017) 7(9514): 1-14 https://doi.org/10.1038/s41598-017-10306-0

[12] D. Snoeck, L. Pel, N. De Belie, Superabsorbent polymers to mitigate plastic drying shrinkage in a cement paste as studied by NMR. Cem Concr Comp (2018) 93: 54-62. https://doi.org/10.1016/j.cemconcomp.2018.06.019

[13] V. Mechtcherine, E. Secrieru, C. Schröfl, Effect of superabsorbent polymers (SAPs) on rheological properties of fresh cement-based mortars - Development of yield stress and plastic viscosity over time. Cem Concr Res (2015) 67: 52-65. https://doi.org/10.1016/i.cemconres.2014.07.003

[14] V. Mechtcherine, C. Schröfl, M. Wyrzykowski, M. Gorges, D. Cusson, J. Margeson, N. De Belie, D. Snoeck, K. Ichimiya, S.-I. Igarashi, V. Falikman, S. Friedrich, J. Bokern, P. Kara, P. Lura, A. Marciniak, H.-W. Reinhardt, S. Sippel, A.B. Ribeiro, J. Custódio, G. Ye, H. Dong, J. Weiss, Effect of superabsorbent polymers (SAP) on the freeze-thaw resistance of concrete: results of a RILEM interlaboratory test. Mater Struct (2017) 50(14): 1-19. https://doi.org/10.1617/s11527-016-0868-7

[15] N. Nestle, A. Kühn, K. Friedemann, C. Horch, F. Stallmach, G. Herth, Water balance and pore structure development in cementitious materials in internal curing with modified superabsorbent polymers studied by NMR. Microporous Mesoporous Mater (2009) 125(1-2): 51-57. https://doi.org/10.1016/j.micromeso.2009.02.024

[16] P. Trtik, B. Muench, W.J. Weiss, G. Herth, A. Kaestner, E. Lehmann, P. Lura, Neutron tomography measurements of water release from superabsorbent polymers in cement paste, in: W. Brameshuber (Ed.) International RILEM Conference on Material Science, RILEM Publications S.A.R.L., Aachen, 2010, pp. 175-185.

[17] M. Wyrzykowski, P. Lura, F. Pesavento, D. Gawin, Modeling of Water Migration during Internal Curing with Superabsorbent Polymers. J Mater Civ Eng (2012) 24(8): 1006-1016. https://doi.org/10.1061/(ASCE)MT.1943-5533.0000448

[18] D. Snoeck, L.F. Velasco, A. Mignon, S. Van Vlierberghe, P. Dubruel, P. Lodewyckx, N. De Belie, The effects of superabsorbent polymers on the microstructure of cementitious materials studied by means of sorption experiments. Cem Concr Res (2015) 77: 26-35. https://doi.org/10.1016/i.cemconres.2015.06.013

[19] D. Snoeck, D. Schaubroeck, P. Dubruel, N. De Belie, Effect of high amounts of superabsorbent polymers and additional water on the workability, microstructure and strength of mortars with a water-tocement ratio of 0.50. Constr Build Mate, (2014) 72: 148-157. https://doi.org/10.1016/j.conbuildmat.2014.09.012

[20] M.T. Hasholt, O.M. Jensen, K. Kovler, S. Zhutovsky, Can superabsorbent polymers mitigate autogenous shrinkage of internally cured concrete without compromising the strength?. Constr Build Mater (2012) 31: 226-230. https://doi.org/10.1016/i.conbuildmat.2011.12.062

[21] E. Gruyaert, B. Debbaut, D. Snoeck, P. Díaz, A. Arizo, E. Tziviloglou, E. Schlangen, N. De Belie, Self-healing mortar with pH-sensitive superabsorbent polymers: testing of the sealing efficiency of selfhealing mortars by water flow tests. Smart Mater Struct (2016) 25(8) 084007: 1-11. https://doi.org/10.1088/0964-1726/25/8/084007

[22] A. Mignon, D. Snoeck, D. Schaubroeck, N. Luickx, P. Dubruel, S. Van Vlierberghe, N. De Belie, pH-responsive superabsorbent polymers: A pathway to self-healing of mortar. React Funct Polym (2015) 93: 6876. https://doi.org/10.1016/i.reactfunctpolym.2015.06.003

[23] J. Pelto, M. Leivo, E. Gruyaert, B. Debbaut, D. Snoeck, N. De Belie, Application of encapsulated superabsorbent polymers in cementitious materials for stimulated autogenous healing. Smart Mater Struct (2017) 26(10): 1-14 https://doi.org/10.1088/1361-665X/aa8497

[24] H.X.D. Lee, H.S. Wong, N.R. Buenfeld, Potential of superabsorbent polymer for self-sealing cracks in concrete. Adv Appl Ceram (2010) 109(5): 296-302. https://doi.org/10.1179/174367609X459559

[25] H.X.D. Lee, H.S. Wong, N.R. Buenfeld, Self-sealing cement-based materials using superabsorbent polymers, in: O.M. Jensen, M.T. Hasholt, S. Laustsen (Eds.) International RILEM Conference on Use of Superabsorbent Polymers and Other New Additives in Concrete, RILEM Publications SARL, Lyngby, 2010, pp. 171-178.

[26] H.X.D. Lee, H.S. Wong, N.R. Buenfeld, Self-sealing of cracks in concrete using superabsorbent polymers. Cem Concr Res (2016) 79: 194-208. https://doi.org/10.1016/i.cemconres.2015.09.008

[27] D. Snoeck, S. Steuperaert, K. Van Tittelboom, P. Dubruel, N. De Belie, Visualization of water penetration in cementitious materials with superabsorbent polymers by means of neutron radiography. Cem
Concr Res (2012) 42(8): 1113-1121.

https://doi.org/10.1016/j.cemconres.2012.05.005

[28] X.F. Song, J.F. Wei, T.S. He, A method to repair concrete leakage through cracks by synthesizing super-absorbent resin in situ. Constr Build Mater (2009) 23(1): 386-391. https://doi.org/10.1016/j.conbuildmat.2007.11.009

[29] D. Snoeck, F. Malm, V. Cnudde, C.U. Grosse, K. Van Tittelboom, Validation of Self-Healing Properties of Construction Materials through Non-Destructive and Minimal Invasive Testing. Adv Mater Interfaces (2018) 1800179. https://doi.org/10.1002/admi.201800179

[30] D. Snoeck, K. Van Tittelboom, S. Steuperaert, P. Dubruel, N. De Belie, Self-healing cementitious materials by the combination of microfibres and superabsorbent polymers. J Intel Mat Syst Str (2014) 25(1): 13-24. https://doi.org/10.1177/1045389X12438623

[31] D. Snoeck, Self-Healing and Microstructure of Cementitious Materials with Microfibres and Superabsorbent Polymers, Struct. Eng., Ghent University, Ghent, 2015, p. 364.

[32] K. Van Tittelboom, J. Wang, M.A. Gomes De Araújo, D. Snoeck, E. Gruyaert, B. Debbaut, H. Derluyn, V. Cnudde, E. Tsangouri, D. Van Hemelrijck, N. De Belie, Comparison of different approaches for selfhealing concrete in a large-scale lab test. Constr Build Mater (2016) 108: 125-137. https://doi.org/10.1016/i.conbuildmat.2015.12.186

[33] G. Hong, S. Choi, Rapid self-sealing of cracks in cementitious materials incorporating superabsorbent polymers. Constr Build Mater (2017) 143: 366-375. https://doi.org/10.1016/j.conbuildmat.2017.03.133

[34] G. Hong, S. Choi, Modeling rapid self-sealing of cracks in cementitious materials using superabsorbent polymers. Constr Build Mater (2018) 164: 570-578. https://doi.org/10.1016/j.conbuildmat.2018.01.017

[35] C. Romero Rodríguez, S. Chaves Figueiredo, E. Schlangen, D. Snoeck, Modeling water absorption in cement-based composites with SAP additions, in: G. Meschke, B. Pickler, J.G. Rots (Eds.) EURO-C 2018: Computational Modelling of Concrete and Concrete Structures, Bad Hofgastein, 2018, pp. 142, 1-10.

[36] C. Edvardsen, Water Permeability and Autogenous Healing of Cracks in Concrete. ACI Mater J, (1999) 96(4): 448-454. https://doi.org/10.14359/645

[37] D. Snoeck, N. De Belie, From straw in bricks to modern use of microfibres in cementitious composites for improved autogenous healing - a review. Constr Build Mater (2015) 95: 774-787. https://doi.org/10.1016/j.conbuildmat.2015.07.018

[38] E.-H. Yang, Designing added functions in Engineered Cementitious Composites, Civil Engineering, University of Michigan, Ann Arbor, 2008, p. 293.

[39] V.C. Li, Engineered Cementitious Composites (ECC) - Material, Structural, and Durability Performance, in: E. Nawy (Ed.), Concrete Construction Engineering Handbook, CRC Press 2008, p. 78. https://doi.org/10.1201/9781420007657.ch24

[40] Y. Yao, Y. Zhu, Y. Yang, Incorporation of SAP particles as controlling pre-existing flaws to improve the performance of ECC. Constr Build Mater (2011) 28(1): 139-145. https://doi.org/10.1016/i.conbuildmat.2011.08.032

[41] A.E. Brüdern, V. Mechtcherine, Multifunctional use of SAP in strainhardening Cement-based Composites, in: O.M. Jensen, M.T. Hasholt, S. Laustsen (Eds.) International RILEM Conference on Use of Superabsorbent Polymers and Other New Additives in Concrete, RILEM Publications S.A.R.L., Lyngby, 2010, pp. 11-22.

[42] J.S. Kim, E. Schlangen, Super absorbent polymers to simulate self healing in ECC, in: K. van Breugel, G. Ye, Y. Yuan (Eds.) 2nd International Symposium on Service Life Design for Infrastructures, RILEM Publications SARL, Delft, 2010, pp. 849-858.

[43] D. Snoeck, N. De Belie, Repeated autogenous healing in strainhardening cementitious composites by using superabsorbent polymers. J Mater Civ Eng (2015) 04015086: 1-11. https://doi.org/10.1061/(ASCE)MT.1943-5533.0001360

[44] D. Snoeck, P. Van den Heede, T. Van Mullem, N. De Belie, Water penetration through cracks in self-healing cementitious materials with superabsorbent polymers studied by neutron radiography. Cem Concr Res (2018) 113: 86-98. https://doi.org/10.1016/j.cemconres.2018.07.002

[45] D. Snoeck, J. Dewanckele, V. Cnudde, N. De Belie, X-ray computed microtomography to study autogenous healing of cementitious materials promoted by superabsorbent polymers. Cem Concr Comp (2016) 65: 83-93. https://doi.org/10.1016/i.cemconcomp.2015.10.016 
[46] J. Wang, A. Mignon, D. Snoeck, V. Wiktor, N. Boon, N. De Belie, Application of modified-alginate encapsulated carbonate producing bacteria in concrete: a promising strategy for crack self-healing. Front Microbiol (2015) 6(1088): 1-14.

https://doi.org/10.3389/fmicb.2015.01088

[47] J. Wang, D. Snoeck, S. Van Vlierberghe, W. Verstraete, N. De Belie, Application of hydrogel encapsulated carbonate precipitating bacteria for approaching a realistic self-healing in concrete. Constr Build Mater (2014) 68: 110-119.

https://doi.org/10.1016/j.conbuildmat.2014.06.018

[48] F. Altmann, V. Mechtcherine, Durability design strategies for new cementitious materials. Cem Concr Res (2013) 54: 114-125.

https://doi.org/10.1016/i.cemconres.2013.08.008

[49] D. Snoeck, P. Criel, Voronoi diagrams and self-healing cementitious materials: A perfect match. Adv Cem Res (2018). https://doi.org/10.1680/jadcr.16.00091 